\title{
POR UMA POÉTICA DA CONSAGRAÇÃO DA PALAVRA E DA IMAGEM: AS REALIZAÇÕES ARTÍSTICAS DO DIRETOR LUIZ FERNANDO CARVALHO
}

\section{FOR A POETIC OF CONSECRATION OF WORD AND IMAGE: LUIZ FERNANDO CARVALHO'S ARTISTIC ACHIEVEMENTS}

\author{
Cristiane Passafaro Guzzi'
}

\begin{abstract}
RESUMO: Desde as primeiras obras audiovisuais para a TV, o diretor brasileiro Luiz Fernando Carvalho vem nos apresentando um intenso trabalho que ora joga, ora mescla com os limites existentes entre a Palavra e a Imagem sequencializada por um suporte sincrético. Nesse sentido, por intermédio de uma revisitaçâo teórica sobre os estudos sobre literatura e cinema, literatura e televisâo, e mediante o trabalho de traduçáo crítica das informaçôes estéticas transpostas do verbal para o visual, via reflexâo de Haroldo de Campos (2006), pretendemos indiciar uma espécie de síntese de uma "poética da Consagraçăo da Palavra e da Imagem" presente nas realizaçôes do diretor em questăo.
\end{abstract}

Palavras-chave: Luiz Fernando Carvalho; literatura; cinema; televisāo; traduçāo crítica.

ABSTRACT: Since the first audiovisual works for TV, the brazilian director Luiz Fernando Carvalho has been presenting us with an intense work that now plays, sometimes mixed with the limits between a Word and an Image sequenced by a syncretic support. In this sense, by means of a theoretical revision on the studies on literature and cinema, literature and television and through the work of critical translation of aesthetic information transposed from the verbal to the visual, through reflection by Haroldo de Campos (2006), we intend to indict a kind of synthesis of a "poetics of Consecration of the Word and of the Image" present in the achievements of the director in question.

Keywords: Luiz Fernando Carvalho; literature; cinema; television; critical translation.

O paradoxo de ver um filme reside de ser só cinema exato no momento do seu começo, na tela ainda em branco - e que permanece em branco, quando nada ainda foi projetado na sua superfície. O que faz com que a literatura seja literatura, que a linguagem escrita em um livro seja literatura é uma espécie de ritual prévio que traça o espaço da consagraçâo das palavras. Poderia, substituindo a palavra literatura pela palavra cinema, dizer entâo que o que faz com que um

Pós-Doutoranda, em Estudos Literários, pela UNESP/FCLAr (2016), com Bolsa CAPES/PNPD. Realizou parte de seu Doutorado no exterior na UCLA, Los Angeles (EUA). Pesquisadora do Grupo CASA desde 2007, do Grupo GEN - Grupo de Estudos da Narrativa, desde 2013. Colabora como pesquisadora do LABRFF- Los Angeles Brazilian Film Festival, Los Angeles, desde 2014. 
filme seja cinema, que a linguagem visual de um filme seja cinema, é o espaço da consagraçâo das Imagens.

Luiz Fernando Carvalho (2007, pp. 47-48)

O texto literário, ao ser traduzido para outro meio, tem a especificidade de nos convocar, pela leitura, para um jogo sinestésico em que as correspondências visuais, auditivas, táteis, com manifestaçôes de outros sentidos - paladar/olfato - emergem dos signos verbais e năo-verbais em movimento, tecendo o fio em que se enredam essas sensaçóes, em uma espécie de processo de alquimia que poucos diretores dominam com maestria. A significaçăo final produzida, a partir dos sentidos, vai se impondo no espaço entre obra e leitor, realizaçâo e espectador, de tal forma que se esvaem os limites nessa interaçâo. Diante dessa experiência, vemo-nos, em segunda instância, diante de um leitor ousado que, recriando sentidos, faz-se como um realizador autoral que, a cada nova minissérie, estabelece uma continuaçáo de suas obras anteriores, fundando sua própria tradiçăo, mas, principalmente, inaugurando e despertando plurais sentidos para o cenário do audiovisual brasileiro. Sem ineditismo na convocatória, estamos falando do diretor brasileiro Luiz Fernando Carvalho, re-inventor da tradiçáo e vanguardista no trato tanto da Palavra quanto da Imagem.

As realizaçôes televisivas de Carvalho consistem em um processo de profunda pesquisa, enfrentamento do texto e emergência das possibilidades de diálogo, tanto com o texto a ser trabalhado como, e principalmente, com o repertório de leitura que o autor do texto em questăo imprime em suas produçóes. Esse resgate pode ser construído na obra transposta para um novo meio, que oferece diversas possibilidades de compreensăo, que remete nâo somente ao autor da obra literária, mas a esse Carvalho autoral que consegue, antropofagicamente, transpor o que era do universo literário da obra e do autor. Desde suas primeiras obras audiovisuais para a TV, encontramos um intenso trabalho que ora joga, ora mescla com os limites existentes entre a palavra e a imagem sequencializada por um suporte sincrético. Tal trajeto estético passa, desde a realizaçăo do seu filme Lavoura Arcaica (a partir do livro homônimo de Raduan Nassar), pela série Os Maias (a partir do romance de Eça de Queirós) e, de forma ainda mais evidente, pelas minisséries Hoje é dia Maria (primeira e segunda jornadas, a partir do texto dramatúrgico de Carlos Alberto Soffredini), A Pedra do Reino (transposiçâo do Romance d'A Pedra do Reino, de Ariano Suassuna), Capitu (aproximaçáo do romance Dom Casmurro, de Machado de Assis), Alexandre e outros heróis (a partir da releitura de dois contos do escritor Graciliano Ramos, intitulados "O olho torto de Alexandre" e "A morte de Alexandre"), só para citarmos alguns de seus trabalhos com obras notórias da literatura brasileira.

Para o diretor, há uma preocupaçăo educacional com os conteúdos selecionados para seus projetos e que passam pela escolha de obras notórias do cânone, mas aliadas à questăo principal da valorizaçâo do universo brasileiro e afirmaçăo de nossa identidade em uma educaçăo dos sentidos. Há todo um cuidado na ressignificaçâo da palavra ao ser transformada em imagem pelo processo de transposiçăo de Carvalho, que chega a consolidar uma missâo estética e educacional de fazer e apreender obras literárias transpostas para um formato televisivo popular, de grande alcance. Contudo, o que parece diferenciar Carvalho é o estabelecimento de um estudo aprofundado da 
obra, da crítica, da tradiçăo, e, principalmente, das reverberaçóes que a produçâo dos escritores selecionados produzem no cenário ficcional. Tais contribuiçóes nos permitem considerá-lo como um diretor que parece estar firmando, também, seu lugar em nossa literatura televisiva. Como se, além das referências audiovisuais, a obra de Luiz Fernando constituísse também uma referência literária, uma espécie de crítica contemporânea e em novo suporte, da literatura.

O que parece interessar as produçôes audiovisuais de Carvalho é a demarcaçăo do espaço do texto literário na televisâo, trazendo, assim, aproximaçôes e respostas por meio de transformaçóes, rupturas. Nota-se a consolidaçâo de seu trabalho a partir de "[...] um campo de experimentaçâo privilegiada de escrita literária" (DEBS; PALATNIK, 2008, p. 78), uma vez que se há fidelidade (e, somente neste contexto, podemos usar este termo) é, justamente, com a palavra escrita e com o que ela engendra de potencialidades imagéticas para este realizador, seja pelo conformismo, seja, quase majoritariamente, pelo risco.

\section{Da palavra à imagem: aproximações}

A literatura e o cinema, em sua tradiçăo, notoriamente reverberam as influências diretas que diversas manifestaçōes artísticas engendraram uma na outra. A diversidade dos meios pelos quais a arte se propaga hibridiza a linguagem, transpondo a língua escrita e fazendo com que a literatura circule em vários tipos de suportes. Ainda assim, há que se pensar nos limites e nos achados que tais linguagens provocaram e criaram para traduzirem, cada uma ao seu modo, com sua especificidade, a tentativa de uma mesma palavra, uma mesma imagem, avaliando sua presença em novos contextos, no jogo entre tradiçâo e invençâo. A palavra, retirada de um contexto, posta em outro, já nâo é a mesma para compor a atmosfera da encenaçăo, seja ela entre textos verbais, seja entre textos de diferentes linguagens.

Considerados como estruturas semióticas, o discurso verbal e o discurso visual săo irredutíveis um ao outro e, por isso, os autores que discutem suas relaçóes costumam examinar as semelhanças no conteúdo e as diferenças básicas entre os textos literários e suas transposiçôes para diferentes suportes, como o cinema e a televisăo. A passagem de um sistema verbal para um sistema náo-verbal implica um processo de transformaçăo e traduçăo. Nesse processo, as diferenças entre o texto de partida e o de chegada sâo evidenciadas na maneira como os conteúdos săo expressos, favorecendo, assim, o surgimento de um constante fluxo intertextual. Este é possível de ser estudado, em um todo reconhecível e organizado, se pensarmos que tais. ${ }^{2}$ Para a semiótica, há, inclusive, o consenso de tratar todas as linguagens, seja musical, pictórica, gestual, a partir de um mesmo suporte metodológico de descriçấo, uma vez que todas elas sâo consideradas discursos.

A palavra, na transposiçâo do signo verbal para a encenaçâo fílmica ou televisiva, entre outros modos de expressăo, constitui-se apenas como um ponto de partida, pois a

Para a semiótica francesa, há o consenso de tratar todas as linguagens, seja musical, pictórica, gestual, a partir de um mesmo suporte metodológico de descriçáo, uma vez que todas elas sâo consideradas discursos. 
transposiçăo de signos depende năo somente dos efeitos de sentidos construídos pelos enquadramentos realizados pela câmera - os quais levam em consideraçâo os gestos, as entonaçôes e os olhares dos atores -, mas, sobretudo, do modo como o realizador da passagem seleciona, combina e traduz, em sua leitura, tais efeitos. Assim, ao buscar a utilizaçấo de outros signos, como o visual, o sonoro, o tátil e o olfativo, cria-se uma cadeia de significaçóes que valoriza a fábula por meio de articulaçóes que, aparentemente, no texto puramente verbal, podem nâo se destacar ou, dado o novo contexto, trazer à tona as potencialidades do termo primeiro que encontra um novo espaço para a invençăo do enunciador. Vale ressaltar que o texto verbal, quando em nível sofisticado de expressāo literária, é também múltiplo. Aqui a força pulsa na palavra, no jogo de construçâo de sentido; no texto verbal-visual-auditivo, há a explicitaçăo do que se anunciava no jogo dos elementos sígnicos verbais.

Uma transposiçấo, portanto, é a conjugaçăo e a sincronizaçâo de todas essas camadas de linguagem que, juntas e somente juntas, compóem um todo significante. A sintaxe da linguagem visual, ao trabalhar com o que os discursos diversos podem oferecer, seja na musicalidade, no cromatismo, no ângulo cênico, nos verbos, nas roupas, na gestualidade, contribui para a construçăo de um contínuo significativo para interpretaçâo. O texto é, entâo, submetido "[...] a uma enunciaçăo única, a qual confere a necessária unidade à variaçăo", conforme nos ensina a pesquisadora Teixeira (2009, p. 47), em seu texto "Para uma metodologia de análise de textos verbovisuais".

Nas transposiçóes realizadas, um mesmo conteúdo, ou parte significativa dele, parece migrar de um texto para outro. Sendo, todos, textos estéticos, "[...] a íntima coesăo entre [um] conteúdo, que permite o trânsito intertextual, e uma expressâo diversa, que o[s] atualiza[m], nâo pode senáo relativizar os diferentes textos de algum modo." (BALOGH, 2005, p. 51). Essa relativizaçăo homogeneíza, de certa forma, a velha querela existente entre compreender um texto em suas diversas camadas separadamente ou trabalhar o mesmo, de modo que cada linguagem, em contínua relaçăo, venha constituir um metonímico sentido para uma concepçấo de significaçăo de um todo global e englobante.

Verifica-se, ainda, nesse processo de transposiçăo de linguagens, uma mudança nos procedimentos de citaçấo, o que nos permite aproximar tal processo do conceito de traduçăo intersemiótica. Jakobson (1969) define que há três espécies de traduçăo, classificadas de acordo com a forma como interpretam os signos verbais. A primeira é a traduçâo intralingual ou "reformulaçâo", que interpreta os signos verbais por meio de outros signos dessa mesma língua; a segunda é a interlingual ou "traduçấo propriamente dita", que interpreta os signos verbais por meio de signos de alguma outra língua; e a terceira é a intersemiótica ou "transmutaçăo", que interpreta os signos verbais por meio de signos năo-verbais.

As transposiçóes que utilizam o texto verbal como ponto de partida enquadramse nesse terceiro tipo existente de traduçăo, o que nos permite cotejar o processo de manifestaçấo do objeto sincrético a um ato de traduçăo e, consequentemente, a um engendramento complementar ou outro do texto de que se parte, uma vez que estamos diante de distintas semióticas. A traduçâo entre sistemas, nesse sentido, pode ser entendida como uma forma rigorosa de leitura crítica do material que deve ser selecionado e combinado de acordo com as especificidades dos suportes presentes no processo. 
Para Sant'Anna, em seu livro Párodia, Paráfrase e C.ia (1985, p. 18), “[...] desde Goethe, passando por Walter Benjamin até Roman Jakobson e Octavio Paz, têm-se levantado as nuanças da traduçâo como criaçăo, transcriaçăo, invençăo e estilizaçăo". $O$ ato de traduzir, portanto, leva em consideraçâo o trabalho do poeta ao fazer escolhas referentes ao universo que ele pretende abordar de maneira que náo somente o sentido literal provoque um significado, porém sua escolha, posiçăo e intençâo produzam um sentido que, de imediato, talvez năo reconheçamos e, por conseguinte, estranhemos.

Assim, tornam-se importantes as contribuiçóes acerca do assunto, feitas pelo poeta, escritor, ensaísta, crítico e tradutor Haroldo de Campos. Para ele, traduzir é transcrever e reinventar; é diminuir as fronteiras geográficas e textuais de duas línguas, aproximando suas estéticas e suas culturas; é a ampliaçăo e a ressimbolizaçăo da palavra poética. $O$ estudioso considerou o ato de transcriar como sendo iniciado pela percepçấo e pelo exame dos eixos articulares do texto. Transcriar é o maior reflexo da angústia de exprimir o inexprimível, é manter o caráter intraduzível do texto original.

Ao fazer substituiçôes e deslocamentos, o tradutor busca dilatar o efeito de estranhamento provocado pelo imaginário do autor do texto original. Na produçáo poética de Campos, a prática de transcriar está ligada ao ato de atravessar o texto, de medir o infinito, ressimbolizando a obra e mergulhando na dança das palavras, pois o tradutor de poesia pode ser considerado como "[...] um coreógrafo da dança interna das línguas, tendo o sentido [...] năo como meta linear de uma corrida termo-a-termo, [...] mas como um bastidor semântico ou cenário pluridesdobrável dessa coreografia móvel" (SILVA, 2006, p. 280-281).

\section{0 poeta realizador: o caso do diretor Luiz Fernando Carvalho}

Nesse sentido, torna-se possível pensarmos na semelhança existente entre o trabalho do diretor e o ato tradutório da poesia. Seu ato transcriador pode ser entendido nâo pelo modo como se traduz para um novo suporte somente o conteúdo da matéria a ser traduzida, mas (e principalmente) como se traduz o próprio signo, ou seja, sua fisicalidade, sua materialidade, entrevendo, pela imagem, o que o texto sugere ou provoca, conforme pontua Campos (2006, p. 31). Carvalho, dessa forma, enquanto leitor e enunciador, parece sentir-se à vontade tanto no universo da palavra quanto no da imagem, mobilizando recursos cinematográficos e procedimentos tradutórios diversos. Realiza, pois, um produto televisivo que resulta numa fusăo de linguagens, marcado por uma distinta construçăo e revelaçấo que se mostram desde no fazer, no seu pensar e, sobretudo, no seu ser/estar/mostrar-se visualmente.

A partir da proposta presente no trabalho do crítico e filósofo Max Bense, Haroldo de Campos (2006, p. 32) recupera a distinçâo existente entre:

- informaçấo documentária: como aquela que reproduz algo observável, sendo uma sentença-registro;

- informaçăo semântica: vai além do horizonte observável, acrescentando algo que em si mesmo nâo é observável e 
- informaçấo estética: como aquela que transcende a semântica, no que concerne à imprevisibilidade, à surpresa, à improbabilidade da ordenaçấo dos signos.

Sendo esta última a que nos interessa ao tratarmos de textos artísticos, e a partir da constataçăo de que a informaçăo estética năo pode ser codificada a năo ser pela forma em que foi transmitida pelo artista, torna-se possível admitir a possibilidade somente de recriaçăo dos textos a partir de outra informaçaáo estética, autônoma, ligada, por sua vez, por uma relaçâo de isomorfia com o texto primeiro. Como pondera Campos (2006, p. 35), “Entâo, para nós, traduçâo de textos criativos será sempre recriaçâo, ou criaçăo paralela, autônoma, porém recíproca. Quanto mais inçado de dificuldades esse texto, mais recriável, mais sedutor enquanto possibilidade aberta de recriaçáo."

No caso específico de interesse deste nosso texto, o processo de aproximaçấo de textos literários para a televisâo, verifica-se que há, em Luiz Fernando Carvalho, um trabalho que envolve náo só a tentativa de mobilizar diferentes linguagens para a formaçăo de um todo de significaçăo, mas também de recriar, reescrever, tomando emprestado ou acrescentando novos percursos, novas linguagens, mas sempre de modo aproximado com o universo literário escolhido, provocando um efeito de sentido diferente aos públicos atingidos: de "absoluto estranhamento" para o que nâo conhece a obra do diretor, e de "estranhamento esperado" para o público que acompanha a construçăo de sua obra. Nesse processo, verificamos a existência de uma autonomia e considerável liberdade para modificar no texto-base e adequá-lo para a linguagem diferenciada, dada a especificidade do meio sincrético, mas sem perder o fio que ata as duas pontas da produçâo estética. Desse modo, o enunciador da realizaçăo sincrética, ao dialogar com a obra literária, encontra nesta as matrizes para sua invençăo, a partir do seu modo de reutilizaçăo e de reciclagem de materiais diversos para o novo preenchimento estético realizado.

As potencialidades múltiplas do texto sincrético desencadeiam a materializaçâo a provar que só há diferença se, em algum ponto, há identidade. Essa identidade se dará pelo modo como, palimpsesticamente, temos o diálogo aproximado com a obra, e o estabelecimento, concomitantemente, de um desconhecido universo trabalhado a partir da traduçáo e aproximaçăo realizada pelas diferentes linguagens convocadas para a produçáo de uma nova enunciaçăo. Como nos propōe, ainda, Teixeira (2009, p. 63), ao trabalharmos com textos sincréticos, devemos analisá-los mediante um olhar analítico equilibrado, que leva em consideraçâo os elementos dos planos de conteúdo e da expressâo, os componentes tensivos presentes nos textos, bem como seus procedimentos de interaçấo, "[...] já que se consagra de vez a ideia de que é a estratégia enunciativa dos textos sincréticos, único mecanismo capaz de conferir unidade à pluralidade de elementos em jogo, que importa descrever."

Portadores de uma materialidade polissensorial, os textos sincréticos apresentamse como um rico objeto de estudo para compreendermos a articulaçăo e os des-limites entre as diferentes linguagens mobilizadas, bem como verificarmos os diferentes estudos e entradas analíticas que o próprio objeto demanda em seu caminho de análise. Inferimos, assim, que o enunciador-realizador Luiz Fernando Carvalho procura, com seus trabalhos, evidenciar a diferença necessária que um meio televisivo pede ao vislumbrar um público heterogêneo, necessitando trabalhar de modo mais sintético, construído como simples. Tal simplicidade, contudo, năo significa simploriedade, pois 
seus resultados sempre indicam um trabalho de lapidaçăo de sentidos e, por isso mesmo, com frequência, recebem conotaçóes de hermetismo. Todavia, há que se considerar sua tentativa de conciliaçăo entre o popular e o erudito, principalmente, em seu didatismo imagético que escancara a feitura dos procedimentos e nos leva a questionar os limites tênues existentes entre realidade e ficçăo. A tensâo criada pela exploraçáo da alta cultura caindo na tentaçấo de se tornar algo popularizante evidencia a marca autoral de quem se arrisca em escrever encenando, na televisăo, novos e possíveis caminhos.

Nos trabalhos artísticos do diretor, podemos ler a presença de um exercício de reflexâo sobre o fazer em si do ato criacional, principalmente no que se refere à possibilidade de pensarmos na exploraçăo e na evocaçăo do procedimento da funçâo poética numa transposiçăo sincrética, a qual pode ser lida, inclusive, como uma funçâo didática, social, ao compartilhar os andaimes da feitura televisiva. Ao escancarar os bastidores da construçâo da linguagem, expondo a artificialidade dos signos e o caráter representativo da arte, o diretor encontra um artifício (por meio da hiperbolizaçăo e da revelaçăo dos bastidores da criaçăo) para aproximar o público do processo produtivo de sua criaçăo. O didatismo em "náo facilitar", mas em aproximar o espectador e fazê-lo participar desse processo mágico, é revelado pela artificialidade dos signos, uma vez que o realizador parte dos procedimentos da arte para atrair o telespectador, estando, aí, paralelamente, a funçăo didática.

É importante ressaltar que descrever suas obras ou as características marcantes de determinado diretor náo significa, no entanto, pensá-lo como um sujeito detentor e controlador das formas e sentidos por ele produzidos. Mais do que isso, denota, antes, entender a autoria como efeito desse conjunto de "crenças e composiçóes estéticas". Tal conjunto leva o profissional a estabelecer um leque seletivo de regras, códigos, símbolos, escolhas singulares de luminosidade, musicalidade, entre outros, formando, assim, um estilo próprio e reiterativo de criaçáo. Trata-se de uma poética, portanto, que acaba por devorar todas as supostas influências que o diretor parece ter deglutido em sua caminhada experimental.

À guisa dessas reflexôes, postula-se que Carvalho perfilhou, ao longo de suas experimentaçôes profissionais, uma poética singularizada. De modo evidente, um dos traços de sua coerência composicional assinala-se pela recorrência no uso do conceito de artificialidade. Esse conceito leva em consideraçăo nâo somente a questăo da inserçâo de objetos artificiais em meio a objetos reais (evidência, na materialidade, da mistura entre ficçâo e realidade), como, também, denota um exercício de artifício à mostra e sua consequente elaboraçáo e construçáo escancarada dos procedimentos envolvidos em uma criaçăo artística. Notamos que tal regularidade no fazer artístico é combinada com o que existe de mais tecnológico, em termos de atualizaçáo e recriaçáo dos objetos e procedimentos envolvidos, bem como o que há de mais apurado em procedimentos de filmagem. Cortinas abrindo, cenários sendo modificados durante a cena, personagens reaproveitados, iluminaçăo artificial, podem indiciar, apenas como alguns exemplos, a dimensâo de uma recorrência cuja primeira apreensâo pode causar determinados efeitos de estranhamento ou ambiguidades no contrato a ser estabelecido com o espectador. Há uma singularidade do objeto espetacularizado, dotado de um valor năo -pragmático, trabalhado enquanto uma espécie de objeto-valor, tal qual o cachimbo de Magritte ou um pente que ganha o espetáculo, libertando-se de seu valor utilitário. 
A literatura, dentro da estética carvalhiana, ganha a funçăo de dominante, no sentido jakobsoniano, uma vez que ela submete as outras referências (plásticas, teatrais, cinematográficas, etc) às suas próprias coerçōes. E foi essa atuaçăo de um "enfoque em si mesma" que nos levou a cotejar o diretor Luiz Fernando Carvalho como um escritor televisivo, fazendo uma literatura televisiva, a partir do conceito de literalidade pela imagem. ${ }^{3}$ Pode-se pensar que a poética estabelecida por Carvalho traduz, na forma da TV, a forma do conteúdo da literatura, enriquecendo a "forma do conteúdo" e a "forma da expressăo" da TV. Esse jogo pode ecoar em novos escritores que, vivendo a experiência literária em tempo atual, valham-se, em seus escritos, da inventividade vinda da obra televisiva. Além disso, percebe-se que o diretor recorre à literatura como procedimento em suas transposiçôes, de modo que a literatura nâo apareça como referenciaçáo em sua obra, mas como um aspecto formal que sustenta a espinha dorsal de sua poética.

Desse modo, pode-se refletir que sua contribuiçâo como escritor televisivo nos faz olhar suas produçóes com um amplo leque de referências culturais, etnológicas, literárias, advindas de uma tradiçăo, bem como um olhar atento e peculiar nas mais recentes contribuiçôes que a literatura brasileira contemporânea vem delineando, ao conciliar a simultaneidade dos gêneros do nosso tempo, sem deixar de perder a "tradiçấo do rigor" 4 . Para Baldan (2013, p. 4):

\begin{abstract}
Parece que quanto mais a literatura contemporânea alarga seus limites de gênero (com a hibridizaçáo cada vez mais marcada) e de registros da escrita e de suporte, mais ela busca uma "originalidade" absolutamente literária. Parece que a metaficçăo consegue mais bem traduzir a "literariedade", tăo perseguida desde os formalistas russos. Ao mostrar se fazendo, a literatura parece escolher pra si uma forma de expressăo que náo consegue ser realizada por nenhuma outra forma. Pelo menos, nâo do mesmo jeito.
\end{abstract}

Ao lermos as aproximaçóes do diretor como produçóes contemporâneas que partem de obras já consagradas ou recolhidas de um repertório cultural de nossos antepassados, apoiamos nosso processo de leitura e traduçăo do que há de "literariedade" de cada obra, alertando-nos, a todo o momento, para o fato de que estamos assistindo a uma tentativa de passagem, para um outro sistema, do que é mais significativo e do que é mais caracterizado como literário em sua composiçâo imagética. Na composiçâo do filme Lavoura Arcaica (2001), ao partir do texto literário como roteiro, Carvalho declara:

3 O estamos chamando de literariedade pela imagem sugere, dentro da poética carvalhiana, uma intençâo teórica por trás de suas realizaçōes. Como se, além das referências audiovisuais, a obra de Carvalho constituísse também uma referência literária, uma espécie de crítica contemporânea da literatura em novo suporte. Nesse sentido, vale ressaltar, aqui, ainda, que as relaçóes entre literatura e cinema săo antigas e que há uma infinidade de modos de conceber as adaptaçōes, transposiçōes, transcriaçōes. Neste caso, além da óbvia relaçăo de transposiçâao, há a construçâao da crítica literária como um modo de concepçáo.

4 Termo proferido, muitas vezes, pelo professor e crítico literário Joâo Alexandre Barbosa, em suas aulas, ao se referir ao estilo e à tradiçâo inaugurada pelo escritor Machado de Assis. Para o professor, a obra machadiana inaugura o que ele denominou de "tradiçâo do rigor"; tradiçăo, essa, que se configura a partir de um refinado estilo, sob o qual se desenvolve uma acentuada preocupaçáo com o rigor expresso no caráter palpável dos signos. 
[...] a escolha daquelas palavras que, para além de seus significados, me propiciavam um resgate, respondiam à minha necessidade de elevar a palavra a novas possibilidades, alçando novos significados, novas imagens. Tentei criar um diálogo entre as imagens das palavras com as imagens do filme. Palavras enquanto imagens. Mas que imagens seriam estas? Que histórias teriam estas imagens? (2002, pp. 35-36, grifo nosso)

A essa concepçăo da palavra enquanto imagem soma-se um fazer reflexivo, crítico, que procura questionar os limites do literário, do televisivo, do cinematográfico, misturando, ampliando, subvertendo e recriando tais meios. A seleçăo e combinaçăo das palavras - que melhor traduzam uma imagem do que no literário está configurado - parece ser a primeira inquietaçăo do fazer deste diretor. A imagem, enquanto símbolo próximo da realidade sensível que representa, em detrimento da palavra, que se constitui como um símbolo indireto (elaborado, quase sempre, pela razáo), afasta-se do objeto a ser representado, enquanto, na imagem, temos a presentificaçăo da ideia plasmada pela captaçâo fílmica. Para o cineasta Epstein (1983, p. 97, grifo nosso):

O filme está naturalmente mais apto a reunir as imagens de acordo com o sistema irracional da textura onírica do que segundo a lógica do pensamento da língua, falada ou escrita, em estado de vigília, uma vez que lança máo de imagens carregadas de valências sentimentais. Todas as dificuldades que o cinema tem para expressar idéias racionais prenunciam a facilidade com que é capaz de traduzir a poesia das imagens, que é a metafísica do sentimento e do instinto.

Essa facilidade para traduzir a poesia das imagens parece ser explorada, ao extremo, nas realizaçôes de Carvalho. Produzidas como transposiçōes sincréticas embasadas pela exploraçăo da funçăo poética em suas camadas de significaçăo (atores, cenários, falas, gestos e iluminaçâo), suas minisséries deixam transparecer a verdadeira motivaçâo da linguagem poética que vem a ser, essencialmente, sua tendência imagética. O poeta procura, na palavra, o elemento material de que necessita; fala por intermédio de imagens e tende a valer-se da palavra como uma coisa em si. Analogamente, o diretor busca dar a ver, por meio de imagens, aquilo que parece estar expresso no texto verbal. A materialidade da expressâo literária (de natureza sempre acústica) sugere uma visualidade năo só imagética, mas quase que "palpável". Ao escancarar seus procedimentos de criaçăo artística, em cena e em ato, o diretor presentifica a plasticidade da palavra em seu grau máximo, pois, para ele, "[...] esta é a questăo mais difícil [...]. Como pôr a imagem de pé, e ela ficar ali, viva". (CARVALHO, 2002, p. 104).

A exploraçăo da funçăo poética nas realizaçōes televisivas dá a impressăo de convocar, entre outros sentidos, o da visăo, predominantemente, para dominar o jogo imagético criado. Jakobson (1969, p. 128) situa a funçâo poética, no conjunto das demais funçōes da linguagem, como sendo aquela que promove o "enfoque da mensagem por ela própria". Em outras palavras, ela se centraliza na mensagem a ser transmitida e tende a revelar e explorar os recursos imaginativos criados pelo emissor. A linguagem, tensionada por esta funçáo, apresenta um enfoque em si mesma, direcionando o olhar 
para seu próprio ato de encenaçăo. O movimento, portanto, de traduçăo que é feito no verbal, ao ser pensado de modo transposto para o texto o sincrético, mostra-se seguindo os mesmos princípios de feitura e organizaçăo.

Como traço resultante da traduçáo do estético, a título de análise, temos a exploraçâo de um efeito notoriamente explorado nas três realizaçōes em questăo (Capitu, Hoje é Dia de Maria, A Pedra do Reino, respectivamente): o "escancaramento das metáforas", presente nos textos verbais e trabalhado nas imagens televisivas. A metáfora, trabalhada em sua excelência pelo discurso poético, caracteriza-se, tradicionalmente, em relaçâo analógica ao sentido próprio das palavras. No trato poético dado aos procedimentos mobilizados nas minisséries, há a presença de metáforas evidenciadas pelos gestos, pela atuaçăo e pela encenaçăo das personagens. O texto sincrético faz literalmente, com açôes, o que algumas metáforas sugerem no texto verbal. Em Capitu (2008), a conhecida metáfora que inicia o romance: “O meu fim evidente era atar as duas pontas da vida, e restaurar na velhice a adolescência. Pois, senhor, náo consegui recompor o que foi nem o que fui." (ASSIS, 2008, p. 94), merece destaque pelo acabamento visual dado pela realizaçăo sincrética.

Figura 1 - Plano-sequência 5 de Capitu correspondente ao Capítulo II "Do Livro", do romance Dom Casmurro
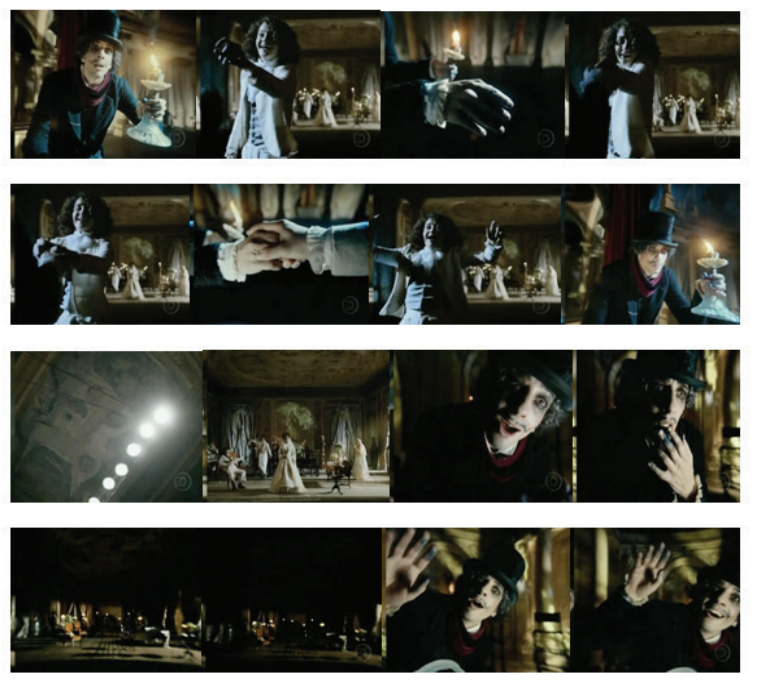

Fonte: DVD Capitu (REDE GLOBO, 2008)

É interessante notar a estratégia enunciativa presente na sequência acima, que insere, em um mesmo plano, e com foco no movimento de "dar-se as măos", o Bentinho, - da adolescência-, com o Bento Santiago, - da velhice. A organizaçâo visual, em um

O conceito de plano é um tanto amplo, e a palavra é utilizada de uma forma diferenciada. Uma definiçấo útil é de que plano é o intervalo que há entre dois cortes, constituindo-se assim como a menor unidade fílmica. Já a sequência constrói-se mediante um conjunto de cenas sem cortes que formam uma grande subdivisáo da narrativa fílmica, com uma relativa unidade interna. Um filme convencional é formado por algumas poucas sequências, cada uma compreendendo uma etapa mais ou menos separada das outras pelos acontecimentos que desenvolve. Sendo assim, optamos pela terminologia de plano-sequência, que, além de definir-se por ser uma sucessividade longa de quadros encadeados sem cortes, também se define por sua autonomia em relaçăo a outras sequências. 
mesmo plano, de tais personagens, dá a ver a metáfora construída pela referida passagem do romance. Nota-se que essa sequência finaliza-se com um resultado disfórico, manifestado pela gestualidade facial da personagem Bentinho que, por náo conseguir atar as pontas de sua vida, solta a măo do narrador. Além disso, evidencia, nas expressóes faciais e na entonaçăo melódica que acompanha a sequência, a denotaçăo da falha e da falta. Como desfecho da cena, as luzes acesas do cenário mostram-se, gradativamente, apagando-se, como em um final de espetáculo; no caso, o espetáculo da vida de Bentinho.

Podemos observar, desse modo, que o poder ilusionista da narrativa e seu consequente estilhaçamento dâo a ver na exploraçâo, reiterada, a visualidade exacerbada das metáforas presentes no romance. Há, em Capitu, tantos outros exemplos do trato com as metáforas pelo visual. Abaixo, selecionamos apenas alguns, uma vez que a extensăo desta discussăo ocuparia, por si só, todo um capítulo.

\section{Quadro 1 - 0 escancaramento das metáforas em Capitu}

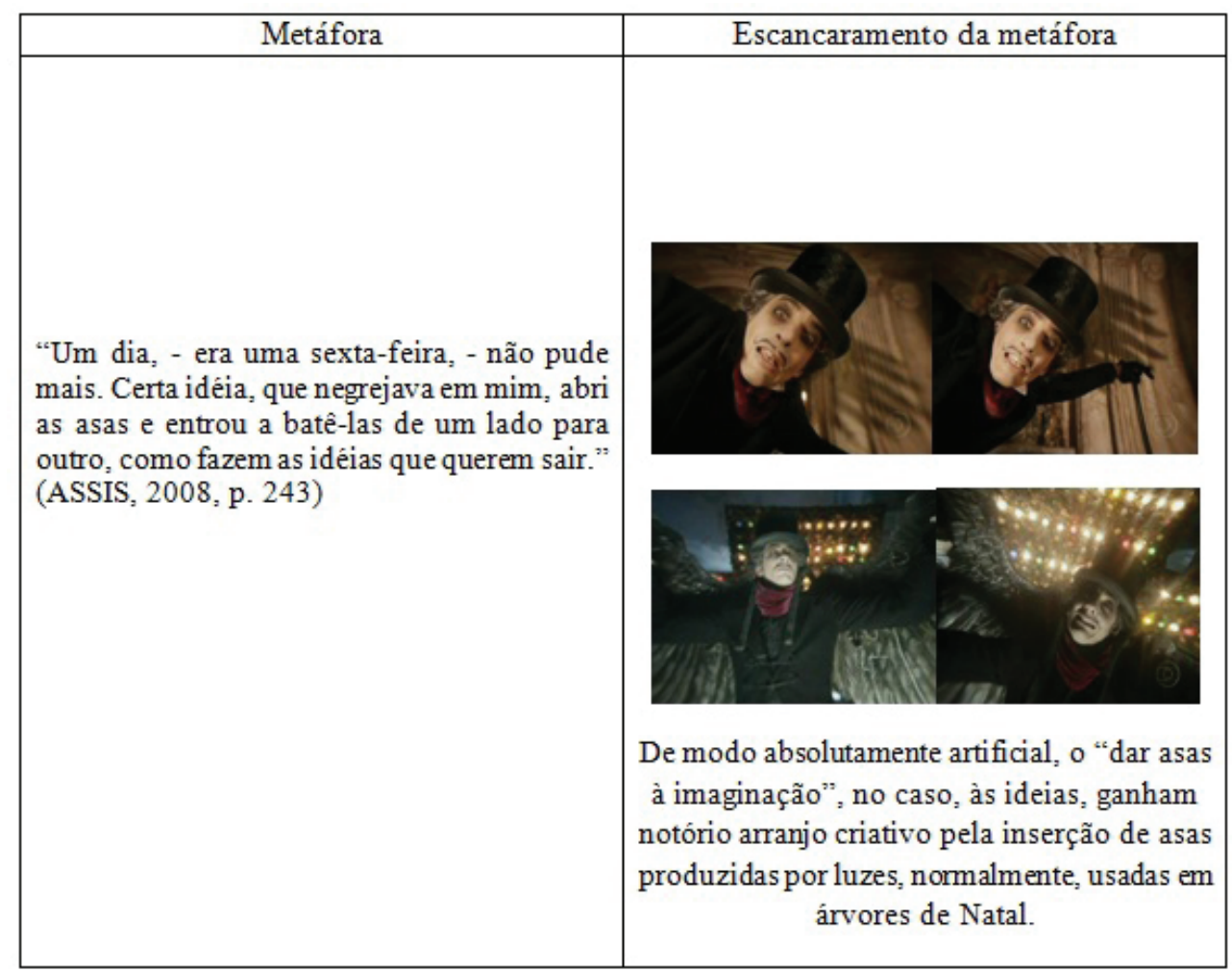

Fonte: DVD Capitu (REDE GLOBO, 2008) 


\begin{tabular}{|l|l|}
\hline Metáfora & Escancaramento da metáfora \\
\hline & \\
$\begin{array}{l}\text { "Tinha-me lembrado a definição que José Dias } \\
\text { dera deles, 'olhos de cigana oblíqua e } \\
\text { dissimulada". Eu não sabia o que era obliqua, } \\
\text { mas dissimulada sabia, e queria ver se podiam } \\
\text { chamar assim. Capitu deixou-se fitar e } \\
\text { examinar. (ASSIS, 2008, p. 159) }\end{array}$ & $\begin{array}{c}\text { Captação, em close, com o registro de câmera } \\
\text { em caleidoscópio. }\end{array}$ \\
& $\begin{array}{l}\text { Tal movimento embaralhado produz um efeito } \\
\text { de dissimulação e de ambiguidade para os } \\
\text { olhos de Capitu. }\end{array}$ \\
\hline
\end{tabular}

\begin{tabular}{|l|l|}
\hline \multicolumn{1}{|c|}{ Metáfora } & Escancaramento da metáfora \\
\hline &
\end{tabular}


Nos textos verbais, sabemos que a metáfora năo é usada somente com a intençăo de deixar a linguagem mais expressiva. Percebemos que a metáfora afeta e interfere nos pensamentos e nas açôes realizadas em toda a narrativa, dando, ao texto, toda a vitalidade e ampliando o alcance do sentido, na medida em que podemos ler, simultaneamente, o sentido literal e a imagem sugerida pela analogia, reconhecendo, inclusive, o procedimento que permitiu tal simultaneidade. Assim, ao lermos de modo expressivo tais nuances, deixa-se entrever, de modo direto, o movimento que a palavra faz quando esta se mobiliza para dizer algo por meio de correspondências.

Em Hoje é dia de Maria (2005), a câmera percorre, em três diferentes ângulos, as seguintes figuras: 1) Madrasta; 2) pedaço do favo de mel e 3)Maria com receio.

Figura 2 - 0 escancaramento das metáforas em Hoje é Dia de Maria

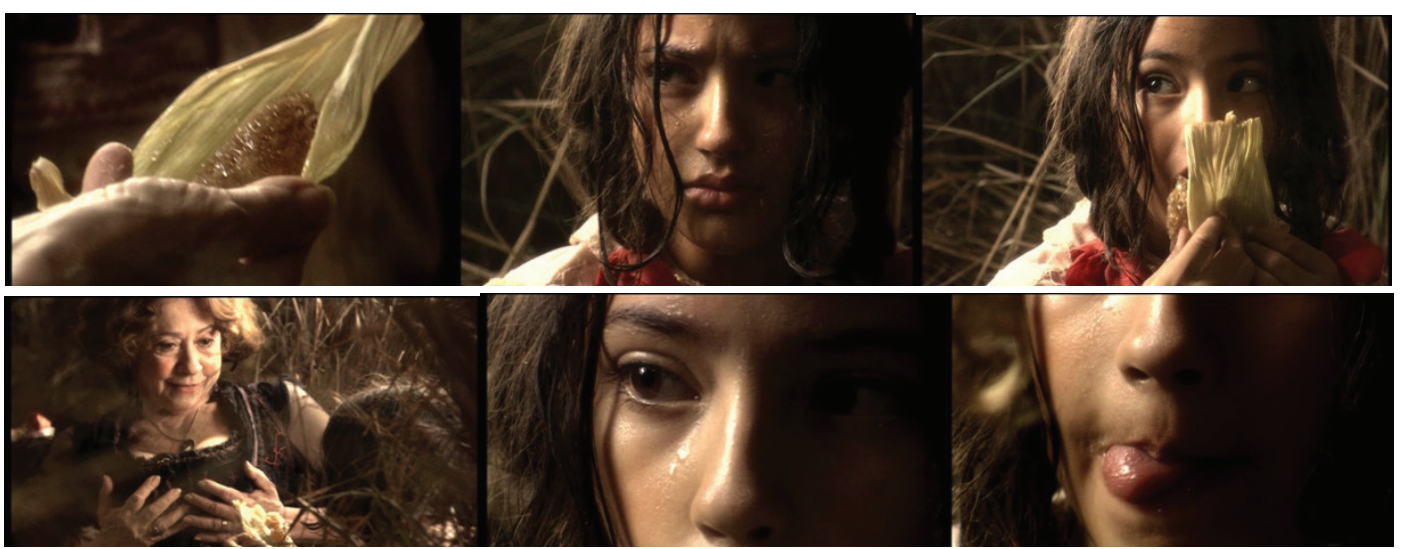

Fonte: DVD Hoje é dia de Maria (REDE GLOBO, 2005)

Essa focalizaçăo direta e separada do objeto (favo de mel) e das personagens (Madrasta e Maria) envolvidas na cena denuncia o escancaramento da própria metáfora a ser enunciada: "hoje ela te dá mel, amanhă há de te dar fel". Esse registro separado, feito pela câmera, alude ao processo que está em jogo e que corresponde à manipulaçấo, pela seduçăo das palavras e pela entrega de um objeto de desejo de quase todas as crianças (doce = favo de mel). Esse recurso fica ainda mais evidente com os zuns realizados pela câmera no rosto, na boca e nos olhos da menina, que escuta, atenta, o poder que a palavra da Madrasta exerce sobre ela, quando saboreia um doce que serve para distraí-la de tal manipulaçăo.

Ainda, há um contraste presente no figurino da Madrasta, - viúva, toda de preto, mas com os seios arfantes, à mostra -, bem como uma rosa e uma fita vermelha, cor da paixăo e do fogo presa no cabelo. Essa caracterizaçăo da Madrasta, com um figurino que se mostra paradoxal, denota o efeito de sentido de ambiguidade que define a personagem: apesar de ser uma das antagonistas da minissérie, a composiçâo de seus trajes e de suas atitudes denuncia traços ora perversos, ora cômicos, que imprimem, no telespectador, uma adesăo a sua figura, ainda que năo por completo.

No terceiro episódio de A Pedra do Reino (2007), intitulado "Os Três Irmáos Sertanejos", Quaderna relata uma espécie de alucinaçâo com a morte, mais 
precisamente, com a figura da Moça Caetana que delineia e figurativiza, por meio de desenhos gráficos e computacionais, o ocorrido com o padrinho de Quaderna, Dom Pedro Sebastiăo, brutalmente assassinado na torre pegada à Capela de Taperoá, no dia 24 de agosto de 1930. Abaixo, há o trecho do roteiro da minissérie em contraste com a resoluçâo sincrética realizada sobre tal passagem:

\section{“11. VILAREJO/ INT/BIBLIOTECA-CASA DE QUADERNA (1938) NOITE}

A MOÇA CAETANA risca o ar com a ponta do indicador. Ela rabisca com letras de fogo uma escrita na parede vazia. Ouve-se a voz de QUADERNA que fala as mesmas palavras que a MOÇA CAETANA escreve na parede.

\section{QUADERNA}

No campo de sono ensanguentado, arde em brasa o Sonho perdido, tentando em vấo reedificar seus Dias, para sempre destroçados.

QUADERNA grita!" (CARVALHO, 2007, p. 16).

\section{Figura 3-0 escancaramento das metáforas em A Pedra do Reino-} Sequência do delírio entre Quaderna e Moça Caetana

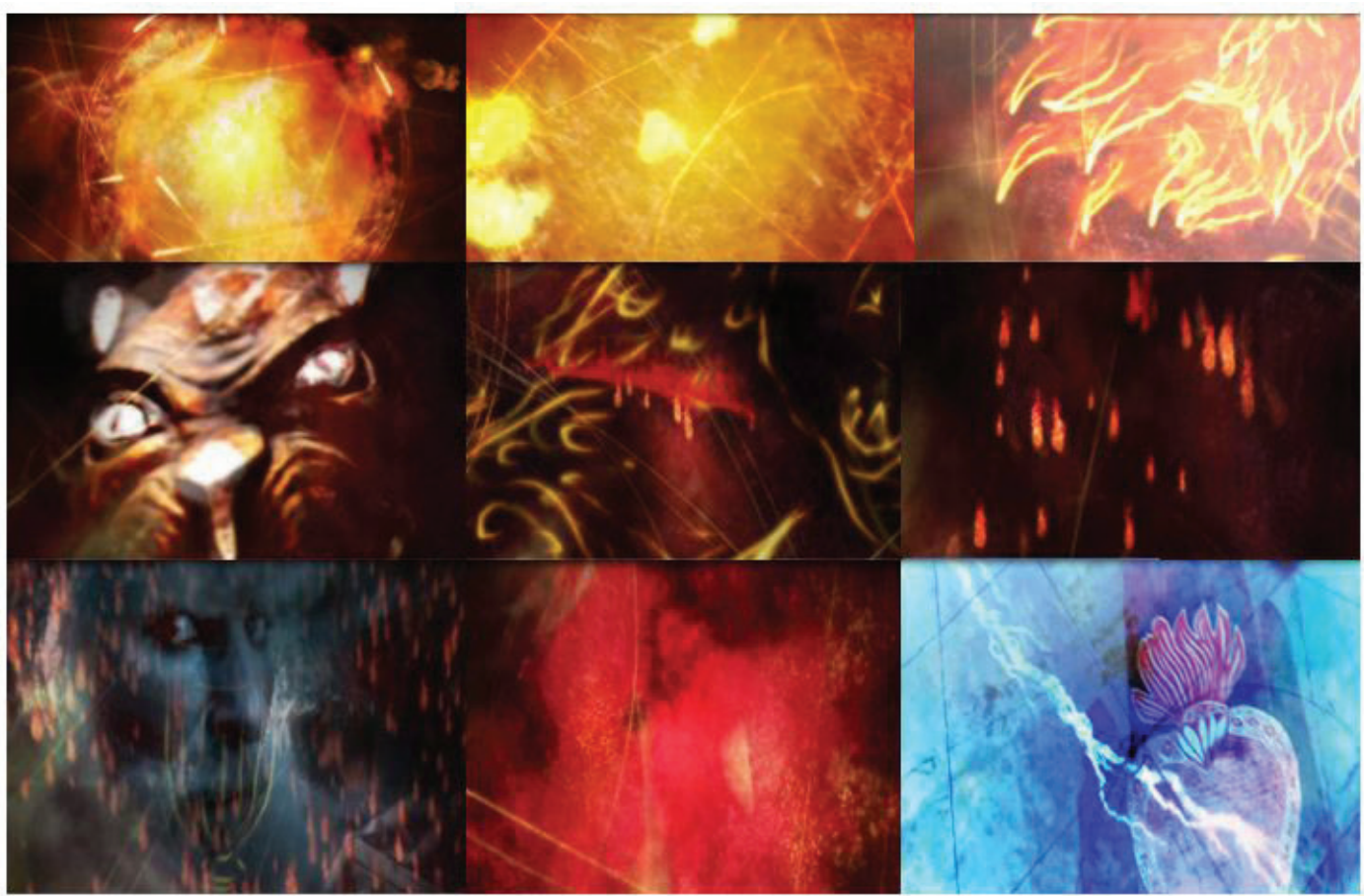

Fonte: DVD A Pedra do Reino (REDE GLOBO, 2007) 
Pode-se notar, em um trabalho que privilegia a densidade presente na mistura de cores pinceladas em tela, uma sequência abstrata que mostra os dizeres metafóricos sobre seu padrinho transformados em imagem. $\mathrm{O}$ arder em brasa evidenciado pela cor estourada amarela é sobreposto pela predominância do vermelho que escorre figurativizando o sangue trazido pela figura gráfica da onça (morte) que emerge no ar. A imagem do rosto do Padrinho, em segundo plano, como um efeito de marca d'água, confirma o enunciado de Quaderna: "No campo de sono ensanguentado, arde em brasa o Sonho perdido, tentando em vâo reedificar seus Dias, para sempre destroçados." A concomitância, inclusive, da açâo realizada pela Onça que desenha no ar tais imagens e a fala de Quaderna em consonância com essa açăo escancara a metáfora de um enigma de morte que talvez seja feito somente por delírios, alucinaçóes, hipóteses da imaginação.

Nas três minisséries sinteticamente referidas aqui, pode-se afirmar que esse recurso da sobreposiçâo de metáforas das narrativas visuais às metáforas verbais revela a criaçấo que aproxima campos semânticos em que o diálogo pela intersecçấo faz ler uma pelas outras. Essa exposiçấo exacerbada promovida pela linguagem, no uso e no mostrar de recursos artificiais, ao longo de suas realizaçōes, retoma e coloca em cena o jogo lúdico e ilusionista existente na literatura, mas potencializado, também, pela imagem plasmada em cena. 


\section{Referências Bibliográficas}

A PEDRA do reino (minissérie). Direçăo: Luiz Fernando Carvalho. Roteiro: Luiz Fernando Carvalho; Luís Alberto de Abreu; Bráulio Tavares. [S.l.]: Rede Globo de Televisăo, 2007. 2 DVD's (4 h 36 min). Produzido por Globo Marcas DVD e Som Livre.

BALDAN, Maria de Lourdes Ortiz Gandini. A funçăo subjetiva na literatura: casos e efeitos. In: ANAIS DO III CONGRESSO INTERNACIONAL CUESTIONES CRÍTICAS: los centros de estudios en literatura argentina y de Teoría y Crítica Literaria, 3, 2013, Rosário. Anais... Rosário, 2013.

BALOGH, A. M. Conjunçôes-Disjunçōes-Transmutaçôes: da Literatura ao Cinema e à TV. 2. ed. rev. e ampl. Săo Paulo: Annablume, 2005.

CAMPOS, Haroldo de. Da traduçâo como criaçăo e crítica. Metalinguagem e outras metas: ensaios de teoria e crítica literária. Săo Paulo: Perspectiva, 2006. pp. 31-48.

CAPITU. Texto: Euclydes Marinho. Colaboraçāo Daniel Piza, Edna Palatnik, Luís Alberto de Abreu. Texto Final e Direçāo Geral: Luiz Fernando Carvalho. Manaus: Sistema Globo de Gravaçôes Audiovisuais, 2009. 2 DVD'S, widescreen, color. Produzido por Globo Marcas DVD e Som Livre. Baseado no romance Dom Casmurro, de Machado de Assis.

CARVALHO, Luiz Fernando. Sobre o filme Lavoura Arcaica. Rio de Janeiro: Ateliê, 2002.

. Diário de elenco e equipe A pedra do reino da obra de Ariano Suassuna. Săo Paulo: Globo, 2007.

DEBS. S.; PALATNIK, E. Do gosto do público, segundo Luiz Fernando Carvalho. Cinémas d'Amérique Latine, n. 16, pp. 74-86, 2008.

JAKOBSON, R. Linguística e comunicaçăo. 2. ed. Traduçāo: Isidoro Blikstein; José Paulo Paes. Săo Paulo: Cultrix, 1969.

HOJE É dia de Maria. Direçâo: Luiz Fernando Carvalho. Intérpretes: Carolina Oliveira, Letícia Sabatella, Rodrigo Santoro, Stênio Garcia, Osmar Prado e Fernanda Montenegro e outros. Roteiro: Luís Alberto de Abreu e Luiz Fernando Carvalho. Distrito Industrial- Manaus: Sistema Globo de Gravaçōes Audiovisuais LTDA, 2006. 3 DVD'S (9h26). Produzido por Globo Marcas DVD e Som Livre. Baseado na obra de Carlos Alberto Soffredini.

SANT'ANNA, A. R. de. Paródia, Paráfrase \& Cia. Sáo Paulo: Ática, 1985.

TEIXEIRA, L. Para uma metodologia de análise de textos verbovisuais. In: OLIVEIRA, A. C. M. Linguagens na comunicaçăo: desenvolvimentos de semiótica sincrética. Săo Paulo: Estaçăo das Letras e Cores, 2009. pp. 41-77. 